$10-5-2020$

\title{
Abriendo Oportunidades strengthens government education programming for indigenous adolescent girls in Guatemala
}

Population Council

Follow this and additional works at: https://knowledgecommons.popcouncil.org/

series_newsletters_researchimpact

Part of the Family, Life Course, and Society Commons, and the Gender Equity in Education Commons How does access to this work benefit you? Let us know!

\section{Recommended Citation}

"Abriendo Oportunidades strengthens government education programming for indigenous adolescent girls in Guatemala," Research Utilization and Impact Brief. Washington, DC: Population Council, 2020. 


\section{Abriendo Oportunidades Strengthens Government Education Programming for Indigenous Adolescent Girls in Guatemala}

For over 15 years, Abriendo Oportunidades has partnered with national and local authorities to improve educational prospects for indigenous girls. In Guatemala, evidence and ongoing technical assistance have helped to strengthen and expand the Ministry of Education's alternative education programs for adolescents, ensuring they are responsive to the needs of indigenous rural communities.

\section{INTRODUCTION}

In Guatemala, indigenous girls are faced with discrimination based on the intersection of gender, economics, and ethnicity. Many live in isolated rural areas with limited access to water, sanitation, passable roads, schooling, and health care.

Indigenous girls confront particular barriers that put them at risk of not pursuing secondary education as well as marrying early and having children at a young age. Providing accessible educational opportunities and developing their life skills may delay and even prevent these risks. ${ }^{1}$ While conditions are improving across Guatemala, school enrollment remains low overall, and indigenous girls are overrepresented among the out-of-school population.

Research carried out by the Population Council in Guatemala has demonstrated that social programs fail to reach the most marginalized populations when they are not specifically designed to meet the needs of these groups. ${ }^{2}$ In response, the Population Council, in collaboration with local and international partners, launched Abriendo Oportunidades (AO) ${ }^{3}$ in 2004 to reach indigenous adolescent girls in rural communities across Guatemala. AO makes critical investments in girls ages $8-18$ to help them successfully navigate

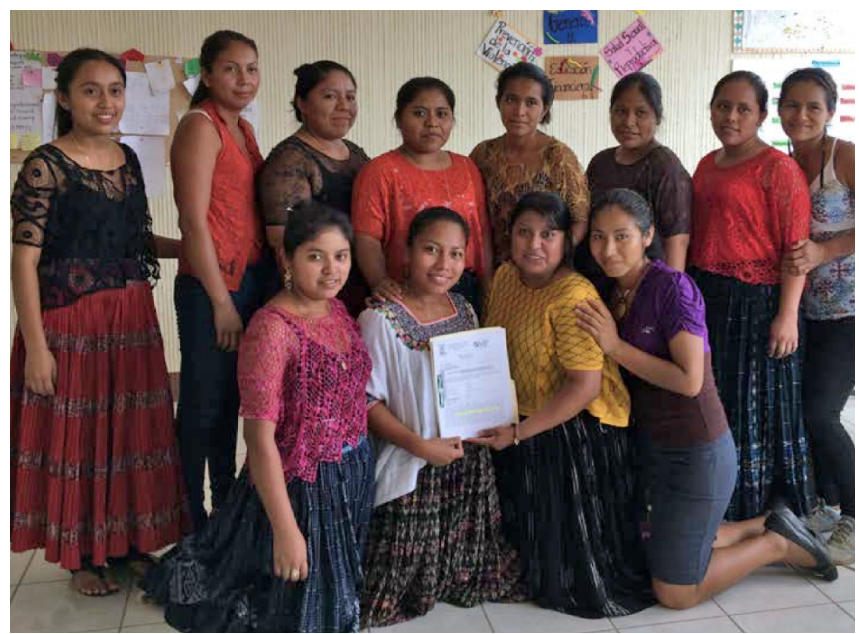

adolescent transitions. The program engages community leaders and establishes community girls' clubs-safe spaces ${ }^{4}$ where girls learn practical skills and assume leadership roles. The program also invests in indigenous female mentors (ages 18-25 years), who run the safe spaces and facilitate regular sessions, receiving tools, trainings, and certifications that enable them to cultivate status as community agents of change. The goals of $A O$ include to strengthen indigenous girls' social support networks, connect them with role models and mentors, build a base of critical life and leadership skills, and provide hands-on professional training and experience. 


\section{RESEARCH SUMMARY}

AO uses a girl-centered approach while also engaging parents, guardians, and community leaders. This includes establishing community contracts signed by local leaders who commit to ensuring the establishment and maintenance of a safe space where girls can gather. Girls in agesegmented groups (ages 8-12 and 13-18) meet on a weekly basis with female mentors for a period of 18 months. They follow a culturally relevant, rightsbased curriculum ${ }^{5}$ that builds life skills and assets, including communication skills, tools to question traditional gender norms, and information on sexual and reproductive rights and health. Mentors are local women ages 18-25 who participate in quarterly trainings to learn new content, improve their facilitation skills, and learn from other mentors' experiences.

Since the pilot phase in 2004 , AO has been implemented in 350 communities across Guatemala, reaching $20,000+$ girls ages $8-18$ and employing $300+$ young indigenous women as mentors.

Results across multiple evaluations demonstrated that program participation delayed child marriage, increased girls' participation in social programs, prevented girls' experience of domestic violence, and increased girls' self-esteem and knowledge of their rights. $\mathrm{AO}$ also fostered positive social change within girls' households and communities, such as increased female autonomy, freedom to meet with friends, and improved status in the home.

\section{RESEARCH USE AND IMPACT}

The Population Council and partners have cultivated close relationships with several government ministries in Guatemala, including the Ministry of Education and the Office of the Defense of Indigenous Women (Defensoría de la Mujer Indígena). To date, the Council has piloted multiple programs with the Ministry of Education's General Directorate for Alternative Education, including Abriendo Oportunidades a la escuela ( $A O$ to School) which combines the $\mathrm{AO}$ model with existing government efforts to improve school re-entry for adolescents.

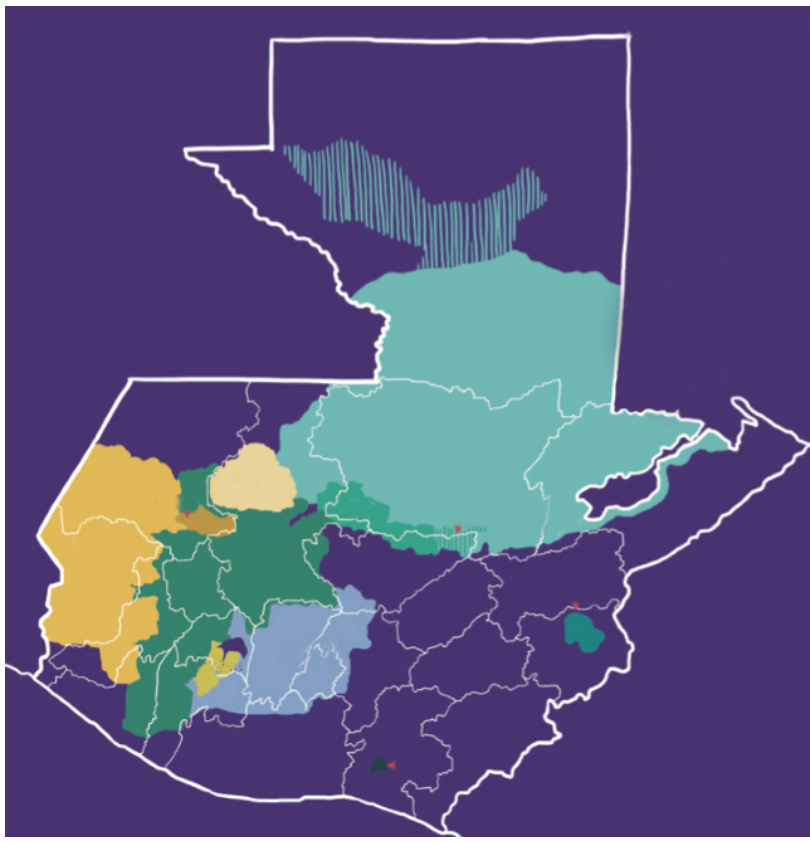

Abriendo Oportunidades currently serves 11 ethnolinguistic groups across 13 of Guatemala's 22 departments.

Supported by AO's evidence-based approach and technical assistance from the Population Council, these pilots have strengthened public education programs and reinforced the Council's role as a valuable partner to the Ministry of Education. Some examples of impact include:

- AO mentors have become tutors certified by the Ministry of Education to provide lower secondary education to out-of-school girls.

- $\quad \mathrm{AO}$ also developed curricula now utilized by the Ministry for all secondary students in its alternative education program (Modalidades Flexibles). ${ }^{6}$

- Through AO to School, the Population Council has provided ongoing technical support to the Ministry of Education to assess the challenges continuing education teachers face in delivering high quality teaching. Assessment findings informed development of a joint teacher training module for all continuing education teachers in the country.

- In addition to now accepting younger adolescents in alternative education programs, the Ministry is exploring avenues to sustain and potentially expand the efforts of $\mathrm{AO}$ to School. 


\section{KEY IMPACTS}

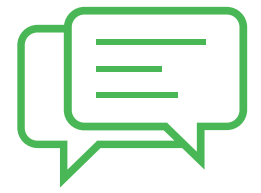

SUSTAINED PARTNERSHIP WITH GUATEMALAN MINISTRY OF EDUCATION AND OFFICE OF THE DEFENSE OF INDIGENOUS WOMEN

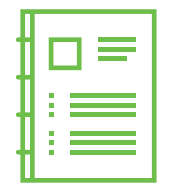

AO CURRICULA ADOPTED FOR USE IN NATIONAL ALTERNATIVE EDUCATION PROGRAM

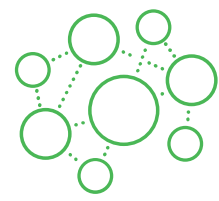

PROFESSIONAL NETWORKS OF ALUMNI MENTORS REGISTERED AS INDEPENDENT COMMUNITY ORGANIZATIONS

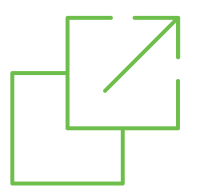

PROGRAM TRANSLATED ACROSS LATIN AMERICA TO PROJECTS IN MEXICO AND BELIZE
Beyond strengthening Ministry of Educationsupported programs, the ripple effects of $A O$ are felt in communities throughout Guatemala and beyond.

- Several AO alumni professional networks, including REDMI (Red de Mujeres Indígenas de Abriendo Oportunidades) Aq'ab'al, and Na'leb'ak, now operate independently as registered nongovernmental organizations (NGOs), supporting the participation of indigenous girls and women in civil society, community development, and local governance.

- Due to the reputation of AO mentors as advocates within their communities, program mentors in Chisec have been invited by the Office of the Mayors to participate in the municipal council, advising on gender and youth programs.

- Examples of regional program translation can be seen in similar projects that have emerged in Yucatan, Mexico, ${ }^{7}$ and Toledo, Belize ${ }^{8}$ to address the unique situations of indigenous girls, employing similar program design, curriculum, and evaluation methods.

\section{LOOKING FORWARD}

$A O$ remains committed to investing in the health and well-being of indigenous girls. With an eye toward sustainability, the Council will continue to work with $A O$ mentors on identifying pathways to secure sustainable livelihoods for mentors and girls, including a poultry and vegetable farm in Chisec, Casa Productiva. In addition, the Council is currently providing information about the perspectives and needs of indigenous communities in the context of COVID-19, ${ }^{9}$ and in the years to come will continue to expand access to education and pathways for social inclusion for indigenous girls and women.

\section{For more information, please visit} Abriendo Oportunidades.

\section{KEY RESOURCES}

Materials to Support Programming for Adolescent Girls in Indigenous Communities

Examples of AO-Informed Programming in Other Contexts
Research Brief: Pedaling Toward the Future: Increasing and Maintaining the School Attendance of Adolescent Girls in Indigenous Communities of Rural Guatemala

Case Study: Abriendo Oportunidades ("Opening Opportunities")

Integrated Curriculum Guide: Program Modalidades Flexibles

Integrated Curriculum Guide: Abriendo Oportunidades Program

Brief: Abriendo Futuros: A Program for Rural Indigenous Girls in Yucatan, Mexico

Infographic: Toledo Adolescent Girl Program 
1 Indigenous girls in Guatemala: Poverty and location. https://www. cgdev.org/sites/default/files/archive/doc/books/lewis-lockheededuCaseStudies/lewis-lockheed-chapter6.pdf

2 Pedaling toward the future: Increasing and maintaining the school attendance of adolescent girls in indigenous communities of rural Guatemala. knowledgecommons.popcouncil.org/departments_sbsrpgy/466/

3 Abriendo Oportunidades ("Opening Opportunities"). https://www.popcouncil.org/research/abriendo-oportunidadesopening-opportunities

4 Creating "safe spaces" for adolescent girls. knowledgecommons. popcouncil.org/departments_sbsr-pgy/837/
5 Abriendo Oportunidades: Integrated Curriculum Guide. knowledgecommons.popcouncil.org/departments_sbsr-pgy/592/

6 Program Modalidades Flexibles: Integrated Curriculum GuideSegundo semestre. knowledgecommons.popcouncil.org/ departments_sbsr-pgy/625/

7 Toledo Adolescent Girl Program. popcouncil.org/uploads/pdfs/ Infographic_AdolGirl2014.pdf

8 https://dataverse.harvard.edu/dataverse/ Covid19researchandevaluation.

The work of Abriendo Oportunidades is made possible by the generous support of the Summit Foundation, NoVo Foundation, UNFPA, Tinker Foundation, and Jerry and Diane Cunningham.

The Population Council collaborates with program implementers, policymakers, researchers, and funding partners to advance evidence-based solutions to critical health and development challenges. The Council's research impact briefs feature recent highlights of our ongoing work to ensure evidence is translated into meaningful actions at community, national, regional, and global levels to improve lives around the world.

Recommended citation: "Abriendo Oportunidades Strengthens Government Education Programming for Indigenous Adolescent Girls in Guatemala," Research Utilization and Impact Brief. Washington, DC: Population Council, 2020. 